\title{
THE DETERMINANTS AND CONSEQUENCES OF TAX AVOIDANCE IN INDONESIA: THE EFFECTS OF TOP MANAGEMENT CHARACTERISTICS AND CAPITAL STRUCTURE
}

\author{
Stevanus Pangestu, Irenius Dwinanto Bimo
}

\begin{abstract}
Faculty of Economics and Business - Atma Jaya Catholic University of Indonesia
\end{abstract} Jl. Jend. Sudirman No.51, Karet Semanggi, Kecamatan Setiabudi, Jakarta 12930

Keywords:

board cha racteristics, capital structure, leverage, profitability tax avoidance

Kata Kunci:

Karakteristik dewan, struktur modal, pengaruh, profitabilitas, penghindaran pajak

Coresponding Author: pangestu.stevanus@gmail.com

\begin{abstract}
Tax avoidance is the lawful minimization of income tax by employing legal methods. This study aims to assess the effects of top management characteristics and capital structure on tax avoidance, measured with Effective Tax Rate (ETR). Our panel data comprise public manufacturing corporations, observed from 2010-2015 $(n=452)$. Based on our panel analysis using random effects model on EViews, we find that tax avoidance: (i) is negatively influenced by independent directors (ii) is positively affected by foreign directors; (iii) is influenced by capital structure, measured with firm leverage, and (iv) positively affects current profitability, measured with Return on Equity. Meanwhile, the influence of female directors is found to be nonexistent. We also offer empirical evidence that board of directors' characteristics influence tax avoidance through financing decisions. The findings of this study suggest that firm capital structure determination is motivated by the intention to avoid taxes.
\end{abstract}

\section{SARI PATI}

Penghindaran pajak adalah minimisasi pajak penghasilan yang sah menurut hukum, dengan menggunakan metode hukum. Penelitian ini bertujuan untuk menilai pengaruh karakteristik manajemen puncak dan struktur modal pada penghindaran pajak, diukur dengan Tarif Pajak Efektif (ETR). Data panel kami terdiri dari perusahaan manufaktur publik, diamati dari 2010-2015 $(n=452)$. Berdasarkan analisis panel kami menggunakan model efek acak pada eViews, kami menemukan bahwa penghindaran pajak: (i) dipengaruhi secara negatif oleh para direktur independen (ii) dipengaruhi secara positif ol eh direktur asing; (iii) dipengaruhi ol eh struktur modal, diukur dengan leverage perusahaan, dan (iv) secara positif mempengaruhi profitabilitas saat ini, diukur dengan Return on Equity. Sementara itu, pengaruh direktur perempuan ditemukan tidak ada. Kami juga menawarkan bukti empiris bahwa karakteristik dewan direksi mempengaruhi penghindaran pajak melalui keputusan pendanaan. Temuan penelitian ini menunjukkan bahwa penentuan struktur modal perusahaan dimotivasi oleh niat untuk menghindari pajak. 


\section{INTRODUCTION}

S\&P Global Market Intelligence reveal that many of the 500 largest American companies avoided federal income taxes, e.g. Facebook, Boeing, Google, Apple, and Coca-Cola. Between 2007 and 2015 (https://www.forbes.com/sites/ericervin/2016/12/13/can-trumps-new-taxpolicies-lead-to-higher-dividend-growth/\#36debd1d620f ), S\&P 500 companies paid an average of $26.9 \%$ in income taxes when the official rate was $35 \%$. The motivations for avoiding taxes have been recognized. Lim (2011) showed that tax avoidance significantly reduces cost of debt. Richardson, Taylor, and Lanis (2015) documented positive association between financial distress and corporate tax avoidance, signifying that there would be higher incentives to avoid tax during times of financial crisis. Chaudhry, Yong, and Veld (2016) found that firms would engage more in tax avoidance when there was a decline in the funding status of pension plans.

These empirical findings indicate that tax avoidance could benefit companies and the action to do so is decided by the top management or board of directors (BOD). Conversely, the risks of avoiding taxes have also been established. Hasan, Hoi, Wu, and Zhang (2014) showed that banks (creditors) perceived tax avoidance as the cause of significant risks. This could inhibit firms from obtaining loans. Badertscher, Katz, and Rego (2013) categorized corporate tax avoidance as a risky activity that could impose significant costs on a firm. Albeit the risks such decision possesses, Taylor and Richardson (2014) indicated that remuneration incentives of management personnel are positively associated with tax avoidance. This explains that shareholders do not punish their upper management for avoiding taxes because it could potentially increase after-tax earnings, and consequently, the firm value. Moreover, Semaan (2017) found that there are shareholders who view tax avoidance to be value-enhancing activity.

Tax-avoidance engagements could also be affected by the firm's capital structure. The government of Indonesia attempts to mitigate the probability of corporate tax avoidance through the introduction of the Ministerial Decree of Finance 169/PMK.010/2015 in 2015, concerning the Determination of the Comparison between Liabilities and Capital of Company for the Calculation of Income Tax. A firm could opt to finance its assets through debt or equity securities. Pecking Order theory states its preference toward internal funding. However, if a firm needs finance externally, then debt financing would be selected due to its lower cost of capital, compared to its equity counterpart. A thinly capitalized firm, i.e. one that possesses a greater amount of debt than equity, would create tax benefit from the interest expense arising from tax-bearing liabilities. 
When a firm avoids paying cash taxes, it would not only save firm assets, but also preserve the firm's profit. Despite the permissible nature of tax avoidance, negative consequences could also occur. For example, Chen, Hu, Wang, and Tang (2014) found that tax avoidance behavior increased agency costs and decreased firm value. The strategic measure that was accomplished for long-term shareholder value tumed out to be disadvantageous for the company.

Earlier studies about the effects of BOD characteristics and capital structure have also been done before (Tarus and Ayabei, 2016; Faccio et al., 2016), as well as the influence of tax avoidance on firm performance (Chasbiandani and Martani, 2012). This research differs from others by expanding previous investigations (Chasbiandani and Martani, 2012): we explore how board characteristics affect tax avoidance through capital structure.

Based on our research introduction, we would like to assess (i) whether BOD characteristics influence capital structure and tax avoidance in Indonesian companies, (ii) how firm capital structure affects tax avoidance, and (iii) how tax avoidance influences firm performance, measured with profitability.

\section{Board of Directors and Tax Avoidance}

Desai and Dharmapala (2005) developed a concept to comprehend how management affects tax avoidance. Armstrong, et al. (2015) suggested that agency problems might lead managers to engage in corporate tax avoidance. This indicates that the decision to avoid taxes has to come from the BOD itself; they are in full control of taking such action.

Studies of gender factor in tax avoidance literature are still scarce compared to earnings management or firm performance literatures. Earlier investigations show contradictory results. Some have found that women tend to: (i) supervise or control more effectively, (ii) increase firm value, (iii) be more conservative, and (iv) be more law-abiding. (Gavious et al., 2012; Gulamhussen \& Santa, 2015). Rose (2007), however, showed that there was no relationship between gender and firm performance. Whereas Adams and Ferreira (2009) found a negative relationship between female directors and firm performance. Conceptually, women are considered different from men in terms of ethics, motivations, achievements, and social stereotypes (Gavious et al., 2012). We therefore predict that boards consisting of female members would be more risk-averse and not engage in tax avoidance, which has high political costs.

$H_{1}$ : Female directors negatively influence tax avoidance 
Akbar, Kharabsheh, Poletti-Hughes, and Shah (2017) gave evidence that the presence of independent directors moderates risk-taking behavior. While Richardson, Lanis, and Leung (2014) identified a negative correlation between tax aggressiveness and proportion of outside directors. We predict that the existence of foreign and independent directors would negatively affect tax-avoidance actions due to their non-affiliated positions, which make them more likely to carry out business ethically:

\section{$\mathrm{H}_{2}$ : Independent directors negatively influence tax avoidance}

Additionally, Choi, Sul, and Min (2012) found that foreign outside directors provide expertise and independent monitoring over management. The presence of foreign directors can ensure the ethical actions from the board:

$H_{3}$ : Foreign directors negatively influence tax avoidance

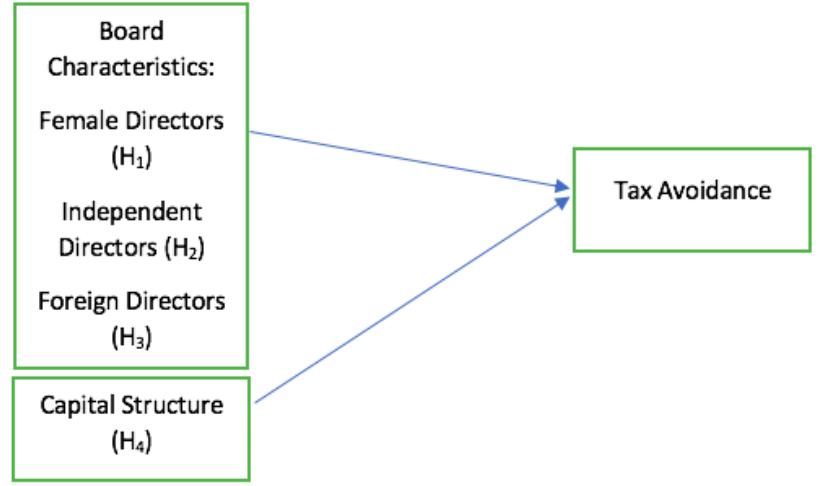

\section{Capital Structure and Tax Avoidance}

Capital structure is a combination of extemal financing that is obtained from debt and equity, and internal financing in the form of retained earnings. The composition of capital structure is a crucial matter because it affects a firm's capability to maximize its value. The Pecking Order theory (Myers and Majluf, 1984) states that in financing activities, companies would prefer intemal to external financing. At such conditions where external financing is required, then debt would be preferred to equity, due to the lower capital cost and the advantage of tax savings.

In China, Chen, Jiang, and Lin (2014) showed that larger firms would favor debt financing, thereby supporting Myers and Majluf's Pecking Order theory. While in South Africa, Ramjee \& Gwatidzo (2012) proved that tax was negatively related to leverage. Pecking Order model shows that tax benefits would arise from the employment of debts. When firms rely more on debt securities, they would benefit from interest expense, which are taxable 
deductions. This would decrease taxable income and consequently, the income tax a firm has to pay.

$\mathrm{H}_{4}$ : Leverage positively influences tax avoidance

Moreover, we would also like to assess whether capital structure intervenes the relationship between BOD and tax avoidance. This is tested to determine whether capital structure decisions are made by board of directors with a consideration to avoid taxes.

$H_{5}:$ Board characteristics influence tax avoidance through capital structure

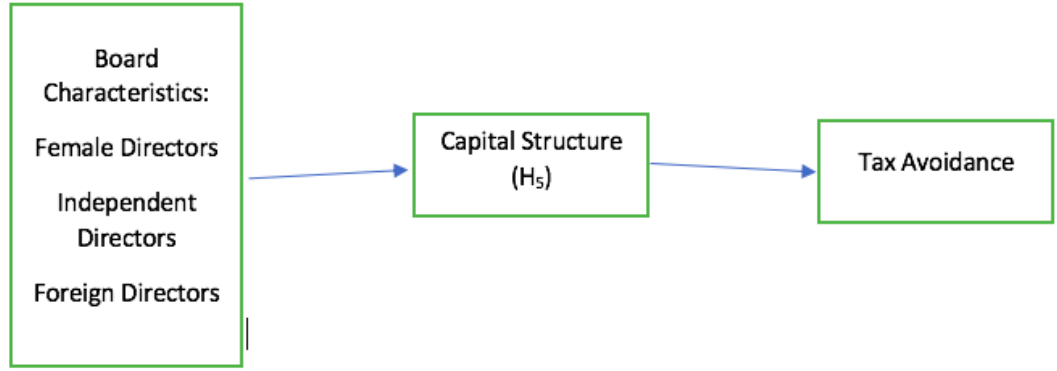

\section{Tax Avoidance and Profitability}

Previous researches on tax avoidance and firm performance have shown inconsistent results (Chen et al., 2014). Desai and Dharmapala (2009) showed that in companies with good corporate governance, tax avoidance is found to increase firm value, while in firms with poor governance, avoiding taxes turn out to be damaging the firm value. A number of studies also argued that tax-avoidance practices require high costs (Khan and Schmidt, 2013; Chen et al., 2014). Costs that are actually paid (e.g. penalty for avoiding taxes) and could potentially occur (e.g. firm value impairment and increase in agency cost). Meanwhile, Chen et al. (2014) found that tax avoidance would increase agency cost and decrease firm value.

Furthermore, Desai and Dharmapala (2009) also argued that avoiding taxes is a form of agency problem, i.e. managerial opportunism. Tax avoidance provides justifications for managers tolower income tax: prioritizing the shareholders first.

Traditional view argues that tax avoidance would increase cash flow to the firm so that it could be used to improve company performance. As firms avoid paying income tax expenses, they would be able to generate more after-tax earnings. This enables firms to generate higher profitability:

$H_{6}$ : Tax avoidance positively influences current profitability 


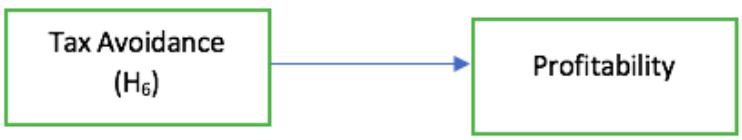

\section{METHODS}

\section{Sample Selection}

Our sample comprised all public manufacturing comorations listed on the Indonesia Stock Exchange from 2010 through 2015. Companies without complete financial information were excluded, along with companies suffering operating losses (Zimmerman, 1983), because it could tamper with income tax calculations. After processes of filtering, the total number of observations was 452 firm-years. Outliers were eliminated for observations that possessed variables whose values were \pm three times the standard deviation.

Table 1. Description of Variables

\begin{tabular}{|c|c|}
\hline Variable & Description \\
\hline$\overline{E T R_{I T}}$ & $\begin{array}{l}\text { Measure of tax avoidance: Income tax expense divided by accounting income } \\
\text { before tax for company i in year } \mathrm{t}\end{array}$ \\
\hline$L E V_{i t}$ & $\begin{array}{l}\text { Measure for capital structure using leverage: Asset-equity ratio for company } \mathrm{i} \\
\text { in year } \mathrm{t}\end{array}$ \\
\hline WOMEN $_{I T}$ & Proportion of BOD members who are female for company $\mathrm{i}$ in year $\mathrm{t}$ \\
\hline$I N D I E_{l T}$ & Proportion of BOD members who are independent for company $\mathrm{i}$ in year $\mathrm{t}$ \\
\hline$E X P A T_{I T}$ & Proportion of BOD members who are foreigners for company $\mathrm{i}$ in year $\mathrm{t}$ \\
\hline $\begin{array}{l}R O E_{i t} \\
\text { Control }\end{array}$ & Return on Equity for company $\mathrm{i}$ in year $\mathrm{t}$ \\
\hline Variables: & Number of years which companyi has been publidy-traded, computed as \\
\hline$L N A G E_{1 T}$ & observed yeari deducted by year of (IPO) listing \\
\hline$L N S I Z E_{I T}$ & Size of company i in year t, measured with natural logarithm of total assets \\
\hline
\end{tabular}

\section{Tax Avoidance Measure}

We employ Effective Tax Rate (ETR) as measure of tax avoidance. It is computed as income tax expense divided by earnings before taxes. The number presents the proportion of generated accounting income, payable as taxes. ETR has been widely used in tax avoidance studies (Stickney and McGee, 1982; Desai and Dharmapala, 2009; Salihu, Obid, and Annuar 2013; Taylor and Richardson, 2014)

\section{Data Analysis}

Our models were analyzed using panel data regression with random-effects on the EViews software: 
I. The effects of capital structure and board characteristics on tax avoidance

$$
E T R_{\mathrm{it}}=\alpha_{0}+\alpha_{1} L E V_{\mathrm{it}}+\alpha_{2} W_{\text {OM }} \mathrm{in}_{\mathrm{it}}+\alpha_{3} I N D I E_{\mathrm{it}}+\alpha_{4} E X P A T_{\mathrm{it}}+\alpha_{5} A G E_{\mathrm{it}}+\alpha_{6} L n S I Z E_{\mathrm{it}}+\varepsilon_{\mathrm{it}}
$$

II. The Indirect Effect of Capital Structure on the Relationship between Board Characteristics and Tax Avoidance

$$
E T R_{\mathrm{it}}=\alpha_{0}+\alpha_{1} M O D E L 1_{\mathrm{it}}++\varepsilon_{\mathrm{it}} ; \text { where }
$$

MODEL 1: $L E V_{\mathrm{it}}=\alpha_{0}+\alpha_{1} W O M E N_{\mathrm{it}}+\alpha_{2} I N D I E_{\mathrm{it}}+\alpha_{3} E X P A T_{\mathrm{it}}+\varepsilon_{\mathrm{it}}$

III. The effect of tax avoidance on profitability

$$
R O E_{\mathrm{it}}=\alpha_{0}+\alpha_{1} E T R_{\mathrm{it}}+\alpha_{2} L n S I Z E_{\mathrm{it}}+\alpha_{3} L n A G E_{\mathrm{it}}+\varepsilon_{\mathrm{it}}
$$

\section{Control Variables}

We include control variables that could affect debt usage and tax avoidance: (a) firm age (b) firm size (c) growth opportunities. Firm age is the length of duration that the firm has been listed in the stock market. Beasley (1996) found that the longer a company had been publicly traded, the more possible for them to make changes in order to comply with public market regulations. Firms with more years of experience would have a better understanding of the rules of the game and therefore more cautious when it comes to avoiding taxes.

We also control for firm size as many previous empirical studies have done, e.g. Desai and Dharmapala (2006). Larger firms have more financing options compared to smaller ones. They also tend to be diversified; acquiring subsidiaries from a range of different industries. Hence the inclusion of total assets as a proxy forfirm size.

\section{RESULTS AND DISCUSSION}

Table 2. Descriptive Statistics

\begin{tabular}{lllllll}
\hline & WOMEN & INDIE & EXPAT & LEV & ETR & ROE \\
\hline Mean & 0.111964 & 0.084360 & 0.206291 & 2.005193 & 0.299018 & 0.155580 \\
Median & 0.000000 & 0.000000 & 0.000000 & 1.740329 & 0.256348 & 0.124509 \\
Maximum & 0.666667 & 0.666667 & 1.000000 & 5.308877 & 0.809589 & 0.594800 \\
Minimum & 0.000000 & 0.000000 & 0.000000 & 1.000000 & 0.001219 & -0.126104 \\
Std. Dev. & 0.161067 & 0.136834 & 0.289699 & 0.912763 & 0.154866 & 0.143227 \\
Skewness & 1.298113 & 1.627160 & 1.156215 & 1.973597 & 1.857855 & 1.528129 \\
Kurtosis & 3.902548 & 5.012297 & 3.009445 & 7.315767 & 6.343135 & 5.325336
\end{tabular}

Observations $452 \quad 452 \quad 452 \quad 452 \quad 452 \quad 452$


The corporations we observed were not highly diverse in terms of gender with an average of 11 per cent women on board of directors. While independent directors averaged $8 \%$ (high variance) and foreign directors averaged 20\% (low variance) across the board. Based on the aforementioned description, it can be determined that women directors, indepen dent directors, and foreign directors are not large in numbers for Indonesian manufacturing corporations.

Furthermore, from LEV, we can conclude that the majority of the corporations finance their assets extemally. ETR averaged $29.9 \%$, which is higher than Indonesia's corporate income tax rate at $25 \%$, reflects the low tax avoidance executed by the corporations. Whereas the industry experienced an average ROE of $15.5 \%$.

\section{Discussion}

\section{The Effects of Board Characteristics and Capital Structure on Tax Avoidance - RANDOM}

$$
E T R_{\mathrm{it}}=\alpha_{0}+\alpha_{1} L E V_{\mathrm{it}}+\alpha_{2} W_{O M E N}+\alpha_{3} I N D I E_{\mathrm{it}}+\alpha_{4} E X P A T_{\mathrm{it}}+\alpha_{5} A G E_{\mathrm{it}}+\alpha_{6} L n S I Z E_{\mathrm{it}}+\varepsilon_{\mathrm{it}}
$$

Table 3. Testing of Hypotheses 1, 2, 3, and 4

\begin{tabular}{|c|c|c|c|}
\hline Variable & Expected sign & Coefficient & P-value \\
\hline $\mathrm{C}$ & $+/-$ & 0.359732 & 0.0002 \\
\hline LEV & - & 0.039972 & $0.0000 * * *$ \\
\hline WOMEN & + & 0.022931 & 0.6730 \\
\hline INDIE & + & 0.160749 & $0.0043^{* * *}$ \\
\hline EXPAT & + & -0.060140 & $0.0840 * *$ \\
\hline LnAGE & & -0.013309 & 0.5233 \\
\hline LnSIZE & & -0.003785 & 0.1564 \\
\hline Adjusted R-Square & \multicolumn{3}{|c|}{0.057397} \\
\hline Prob $>\mathrm{F}$ & \multicolumn{3}{|c|}{0.000014} \\
\hline $\mathrm{N}$ & \multicolumn{3}{|c|}{452 unbalanced observations, 110 cross-sections included } \\
\hline \multicolumn{4}{|c|}{$\begin{array}{l}\text { Dependent variable }=\text { Tax Avoidance (ETR) } \\
\text { Note: Observed variables are in bold letters } \\
\text { LnAGE and LnSIZE are control variables. }\end{array}$} \\
\hline \multicolumn{4}{|c|}{$\begin{array}{l}\text { P-values are one-tailed } \\
\text { Statistical significance is denoted with asterisks: } \\
* * *, * * \text {, and } * \text { correspond to } 1 \%, 5 \% \text {, and } 10 \% \text { levels of significance, respectively. }\end{array}$} \\
\hline
\end{tabular}


Based on regression analysis, INDIE and EXPAT are found to significantly influence ETR at $1 \%$ and $10 \%$ significance levels, respectively. Our observed board characteristics affect tax avoidance, thereby supporting the arguments of previous studies that executives possess significant effects on tax avoidance (Evertsson, 2016; Dyreng et al, 2010).

Table 3 shows that a board consisting of more independent directors would veer away from tax avoidance; accepting H2. This finding corresponds with Richardson, Lanis, and Leung (2014). The existence of independent directors on boardroom proves to be an effective management oversight mechanism, ensuring good corporate governance and neutralizing risktaking and opportunistic behaviors.

Furthermore, EXPAT is revealed to negatively affect ETR; prompting tax avoidance-- H3 is rejected. We can determine that a firm would be more likely to avoid taxes when the board is composed with more foreigners. In their organizational management, they tend to weaken control systems (Schwizer et al., 2013). Their low attendance on board meetings may be due to the fact that foreign nationals are not always present in Indonesia. This condition could explain weakened oversight process. Otusanya (2011) has also found that some multinational companies engage in tax evasion and avoidance. Salihu, Annuar, and Obid (2015) also proved positive relationships between foreign investors' interests and measures of tax avoidance. It could be the case that foreign directors would take part in tax avoidance because foreign presence in companies have their own interests. Expatriates may also not possess the patriotism to contribute wealth to the nations that are not of their nationality.

Meanwhile, $\mathrm{H} 1$ is rejected because the presence of female directors neither causes nor hinders tax avoidance. Siantar (2016) found that board gender diversity did not to affect firm financial performance. It may be possible that the promotion of women on BOD is motivated by reasons for diversity, or the number of female directors on board is just low-the BOD of our observed corporations only averaged $11 \%$ women. As Harris (2014) has shown that the effects of women on top management would be more significant when there are more women directors.

Finally, LEV is found to positively affect ETR at 1 per cent significance level. Companies that employ more debt in financing generate higher ETR or pay more taxes, i.e. not avoiding them. We therefore reject $\mathrm{H} 4$. Our result contradicts the majority of past findings, from Stickney and McGee (1982) to Amidu, York, and Harvey (2016). Moreover, Table 2 shows that the ETR 
variable averages $29.9 \%$, which is higher than the $25 \%$ corporate tax rate. This indicates that Indonesian manufacturing corporations declare their income taxes appropriately.

It may be in the best interests of all stakeholders not to avoid taxes. Leveraged-firms are responsible for honoring their liabilities toward creditors. They already hold business risk, such as credit or default risk, without adding in the risks of tax avoidance.

\section{The Indirect Effect of Capital Structure on the Relationship between Board Characteristics and Tax}

\section{Avoidance}

$E T R_{\mathrm{it}}=\alpha_{0}+\alpha_{1} M O D E L 1_{\mathrm{it}}++\varepsilon_{\mathrm{it}} ;$ where

MODEL 1: $L E V_{\mathrm{it}}=\alpha_{0}+\alpha_{1} W O M E N_{\mathrm{it}}+\alpha_{2} I N D I E_{\mathrm{it}}+\alpha_{3} E X P A T_{\mathrm{it}}+\varepsilon_{\mathrm{it}}$

Table 4. Testing of Hypothesis 5

\begin{tabular}{|c|c|c|c|}
\hline Variable & Expected sign & Coefficient & P-value \\
\hline C & $+/-$ & 0.222987 & 0.0000 \\
\hline MODEL 1 & & 0.040246 & $0.0003^{* * *}$ \\
\hline Adjusted R-Square & & 0.025883 & \\
\hline Prob $>F$ & & 0.000349 & \\
\hline $\mathrm{N}$ & 452 unbalance & rvations, $110 \mathrm{cr}$ & sections included \\
\hline \multicolumn{4}{|c|}{$\begin{array}{l}\text { Dependent variable }=\text { Tax Avoidance }(E T R) \\
\text { Note: Observed variables are in bold letters }\end{array}$} \\
\hline \multicolumn{4}{|c|}{$\begin{array}{l}* * * \text { corresponds to } 1 \% \text { level of significance } \\
\text { The } p \text {-values are one-tailed. }\end{array}$} \\
\hline
\end{tabular}

We present that BOD characteristics affect tax avoidance through capital structure (significant at 1 per cent), therefore accepting $\mathrm{H}_{5}$. We can condude that board characteristics enhance the influence of capital structure on tax avoidance. This finding indicates that one of the decisionmaking considerations for the board to determine capital structure is the possibility of tax avoidance. Financing strategy is executed by firms attempting to manage their taxes.

Capital structure decision is a crucial matter because it has long-term consequences, particularly regarding a firm's going-concern and sustainability. When a company aspires to finance itself by offering capital stock, company control would be shared with the external 
shareholders. Whereas in the events of debt instrument issuance, a firm is faced with default risk, while also experiencing tax shield.

In our investigation, we find that financing decisions are significantly influenced by board characteristics, and one of the considerations in determining capital structure is the possibility of avoiding taxes. The corporations we observed tend to utilize resources that enables tax avoidance.

3. The Effects of Tax Avoidance on Profitability - (Fixed effects model)

$$
R O E_{\mathrm{it}}=\alpha_{0}+\alpha_{1} E T R_{\mathrm{it}}+\alpha_{2} L n S I Z E_{\mathrm{it}}+\alpha_{3} L n A G E_{\mathrm{it}}+\varepsilon_{\mathrm{it}}
$$

Table 5. Testing of Hypothesis 6

\begin{tabular}{|c|c|c|c|}
\hline Variable & Expected sign & Coefficient & P-value \\
\hline C & $+/-$ & & \\
\hline ETR & - & -0.136798 & 0.0000 \\
\hline $\operatorname{Ln} A G E$ & & -0.109167 & 0.0002 \\
\hline LnSIZE & & 0.002725 & 0.2172 \\
\hline Adjusted R-Square & & 0.760482 & \\
\hline Prob $>F$ & & 0.0000 & \\
\hline $\mathrm{N}$ & 452 unbalanc & ervations, 110 & ons included \\
\hline \multicolumn{4}{|c|}{$\begin{array}{l}\text { Dependent variable = Profitability, measured with } R O E \\
\text { Note: Observed variables are in bold letters } \\
\text { LnAGE and } L n S I Z E \text { are control variables. }\end{array}$} \\
\hline \multicolumn{4}{|c|}{$\begin{array}{l}\text { P-values are one-tailed } \\
\text { Statistical significance is denoted with asterisks: } \\
* * *, * * \text {, and } * \text { correspond to } 1 \%, 5 \% \text {, and } 10 \% \text { levels of significance, respectively. }\end{array}$} \\
\hline
\end{tabular}


Table 4 shows that ETR negatively influences ROE at 1 per cent level, which means that lower ETR (higher tax avoidance) increases firm profitability. As a result, $\mathrm{H}_{6}$ is accepted. Our finding supports the traditional view that tax avoidance provides additional resources for the firm to generate income. We can determine from our analysis that top management prioritizes the interests of the firm, and not the country. Resources, which were supposed to be contributed into the income of the state, have been diverted to the shareholders and the management for their use. Additionally, our finding is line with Rego (2003), who found that in the USA, firms with lower taxes have greater income.

\section{CONCLUSION}

Independent directors are found to negatively influence tax avoidance, meanwhile foreign directors affect tax avoidance positively. Capital structure, measured with firm leverage, is revealed to negatively affect tax avoidance. Tax avoidance is also found to positively affect profitability, measured with ROE.

In summary, our findings indicate that composition and characteristics of board of directors directly influence the decision to avoid taxes. Independent directors mitigate tax avoidance, while foreign directors sustain them. Moreover, highly-leveraged firms tend to not avoid taxes for the risks it carries, even though it may increase current firm profitability.

Lastly, it is also suggested that tax avoidance is executed strategically by management through the determination of firm financing activities, as proven by the enhancing effect capital structure has on the relationship between board characteristics and tax avoidance.

\section{MANAGERIAL IMPLICATION}

We offer evidence that financing strategy determines tax avoidance. The implementation of Ministerial Decree of Finance 169/PMK.010/2015 concerning the Determination of the Comparison between Liabilities and Capital of Company for the Calculation of Income Tax can be relevant. The government, through the Directorate General of Taxes (DGT) should socialize and enforce this law to mitigate tax avoidance, in order to increase state income for the country's development. The DGT can also perform tax audit or monitoring by taking BOD characteristics into consideration. Preventing companies from executing base erosion and profit shifting can also be done.

In this research, we only observed publidy-traded manufacturing corporations. Future studies may want to observe companies from different industries because they may employ 
different methods of avoiding taxes. Furthermore, our investigation did not analyze the possibility of difference in employment of corporations' liabilities prior and subsequent to the release of the Ministerial Decree of Finance 169/PMK.010/2015 in 2015.

\section{References}

1. Adams, R.B. and Ferreira, D. (2009). "Women in Their Boardroom and Their Impact on Governance and Performance", Journal of Financial Economics, 94, 291-309.

2. Akbar, S., Kharabsheh, B. Poletti-Hughes, J., and Shah, S.Z.A. (2017). "Board Structure and Corporate Risk Taking in the UK Financial Sector", International Review of Financial Analysis. 50. 101-110.

3. Amidu, M., Yorke, S.M., and Harvey, S. (2016). "The Effects of Financial Reporting Standards on Tax Avoidance and Earnings Quality: A Case of an Emerging Economy", Journal of Accounting and Finance, 16(2), 129-150.

4. Armstrong, C.S., Blouin, J.L., Jagolinzer, A.D., and Larcker, D.F. (2015). "Corporate Governance, Incentives, and Tax Avoidance. Journal of Accounting and Economics", http://dx.doi.org/10.1016/j.jacceco.2015.02.003

5. Badertscher, B.A., Katz, S.P., and Rego, S.O. (2013). "The Separation of Ownership and Control and Corporate Tax Avoidance", Journal of Accounting and Economics. 56. 228250. http://dx.doi.org/10.1016/j.jacceco.2013.08.005

6. Beasley, M.S. (1996). "An Empirical Analysis of the Relation between the Board of Director Composition and Financial Statement Fraud", The Accounting Review. 71(4). 443-465.

7. Chasbiandani, T., \& Martani, D. (2012). “Pengaruh Tax Avoidance Jangka Panjang Terhadap Nilai Perusahaan", Simposium Nasional Akuntansi XV.

8. Chaudhry, N., Yong, H.H.A., and Veld, C. (2016). "Tax Avoidance in Response to a Decline in the Funding Status of Define Benefit Pension Plans", Journal of International Financial Markets, Institutions, and Money. http://dx.doi.org/10.1016/j.intfin.2016.12.004 
9. Chen, J. Jiang, C., and Lin, Y. (2014). "What Determine Firms' Capital Structure in China?", Managerial Finance. 40(10). 1024-1039. http://dx.doi.org/10.1108/MF-062013-0163

10. Chen, X., Hu, N., Wang, X., \& Tang, X. (2014). "Tax avoidance and firm value: evidence from China", Nankai Business Review International, 5(1), 25-42.

11. Choi, H.M., Sul, W., and Min, S.K. (2012) "Foreign board membership and firm value in Korea", Management Decision, 50(2), 207-233, doi: 10.1108/00251741211203533

12. Desai, M. and Dharmapala, D. (2009). "Corporate Tax Avoidance and Firm Value", The Review of Economics and Statistics, 91(3), 537-546.

13. Desai, M.A. and Dharmapala, D. (2006). "Corporate Tax Avoidance and High Powered Incentives", Journal of Financial Economics, 79(1), 145-179.

14. Desai, M.A. and Dharmapala, D. (2005). "Corporate Tax Avoidance and Firm Value", NBER Working Papers 11241. National Bureau of Economic Research

15. Dyreng, S. D., Hanlon, M., \& Maydew, E. L. (2010). "The effects of executives on corporate tax avoidance", The Accounting Review, 85(4), 1163-1189.

16. Evertsson, N. (2016) "Is the top leadership of the organizations promoting tax avoidance?", Journal of Financial Crime, 23(2), 273-288, doi: 10.1108/JFC-06-2014-0028

17. Faccio, M., Marchica, M.T., and Mura, R. (2016). “CEO Gender, Corporate Risk-Taking, and the Efficiency of Capital Allocation", Journal of Corporate Finance. 39. 193-209. http://dx.doi.org/10.1016/j.jcorpfin.2016.02.008

18. Gavious, Ilanit, Einav Segev, and Rami Yosef. (2012). "Female directors and earnings management in high-technology firms", Pacific Accounting Review 24, 1, 4-32.

19. Gulamhussen, M.A., and Santa, S.F. (2015). "Female Directors in Bank Boardrooms and Their Influence on Performance and Risk-Taking", Global Finance Journal. 28. 10-23.

20. Hasan, I., Hoi, C.K., Wu, Q., and Zhang, H. (2014). "Beauty is in the Eye of the Beholder: The Effect of Corporate Tax Avoidance on the Cost of Bank Loans", Journal of Financial Economics. http://dx.doi.org/10.1016/j.jfineco.2014.03.004

21. Harris, C.K. (2014). "Women Directors on Public Company Boards: Does a Critical Mass Affect Leverage?", Business and Economics Faculty Publications. Paper 29

22. Lim, Y. (2011). “Tax Avoidance, Cost of Debt, and Shareholder Activism: Evidence from Korea", Journal of Banking and Finance. 35(2). 456-470. http://dx.doi.org/10.1016/j.jbankfin.2010.08.021

23. Myers, S.C., and Majluf, N.S. (1984). "Corporate Financing and Investment Decisions when Firms Have Information Investors Do Not Have", Journal of Financial Economics. 13. $187-221$. 
24. Otusanya, O.J. (2011). "The Role of Multinational Companies in Tax Evasion and Tax Avoidance: The Case of Nigeria", Critical Perspectives on Accounting , 22(3), 316-332

25. Ramjee, A. and Gwatidzo, T. (2012). "Dynamics in Capital Structure Determinants in South Africa", Meditari Accounting Research. 20(1). 52-67. http://dx.doi.org/10.1108/10222521211234228

26. Rego, S.O. (2003). "Tax-Avoidance Activities of US Multinational Corporations", Contemporary Accounting Research, 20(4), 805-833.

27. Richardson, G., Lanis, R., and Leung, S.C. (2014). “Corporate Tax Aggressiveness, Outside Directors, and Debt Policy: An Empirical Analysis", Joumal of Corporate Finance. 25. 107-121. dx.doi.org/10.1016/j.jcorpfin.2013.11.010

28. Richardson, G., Taylor, G., and Lanis, R. (2015). "The Impact of Financial Distress on Corporate Tax Avoidance Spanning the Global Financial Crisis: Evidence from Australia", Economic Modelling. 44. 44-53. http://dx.doi.org/10.1016/j.econmod.2014.09.015

29. Rose, C. (2007). "Does Female Board Representation Influence Firm Performance? The Danish Evidence", Corporate Governance: An International Review, 15(2), 404-413.

30. Salihu, I.A., Annuar, H.A., and Obid, S.N.S. (2015). “Foreign Investors' Interests and Corporate Tax Avoidance: Evidence from an Emerging Economy", Joumal of Contemporary Accounting and Economics, 11(2), 138-147

31. Salihu, I.A., Obid, S.N.S., and Annuar, H.A. (2013). "Measures of Corporate Tax Avoidance: Empirical Evidence from an Emerging Economy", International Journal of Business and Society. 14(3). 412-427.

32. Schwizer, P., Soana, M. G., \& Cucinelli, D. (2013). "The advantages of board diversity An empirical analysis of the Italian market", Financial Systems in Troubled Waters: Information, Strategies, and Governance to Enhance Performances in Risky Times, 79.

33. Semaan, S.R. (2017). "Tax Avoidance, Income Diversion, and Shareholder Value: Evidence from a Quasi-Natural Experiment.", Available at SSRN: http://dx.doi.org/10.2139/ssrn.2931109

34. Siantar, C.S.D. (2016). "Effects of Board Gender Diversity on Firm Performance and Director Compensation in India", Undergraduate Berkeley Economic Review

35. Stickney, C.P. and McGee, V.E. (1982). "Effective Corporate Tax Rates The Effects of Size, Capital Intensity, Leverage, and Other Factors", Journal of Accounting and Public Policy. 1, 125-152.

36. Tarus, D.K. and Ayabei, E. (2016). "Board Composition and Capital Structure: Evidence from Kenya", Management Research Review. 39(9). 1056-1079. http://dx.doi.org/10.1108/MRR-01-2015-0019 
37. Taylor, G. and Richardson, G. (2014). "Incentives for Corporate Tax Planning and Reporting: Empirical Evidence from Australia", Journal of Contemporary Accounting and Economics. 10. 1-15. http://dx.doi.org/10.1016/j.jcae.2013.11.003

38. Zimmerman, J. (1983). "Taxes and Firm Size", Joumal of Accounting and Economics, 5, 119-149. 